\title{
THE BRITISH JOURNAL OF VENEREAL DISEASES
}

with sulphonamide premedication there is little to choose between the results obtained with sessions of eight and six hours. We are, however, reluctant to draw such a conclusion on the present evidence owing to the small number of cases in the six-hour group and the fact that all our most difficult cases were included in the eight-hour group. The group of post-gonococcal infections is too small for comparison. The group of infections which appeared to be truly non-specific was also small, but as far as the evidence goes it shows that this type of treatment is less effective in these cases and that the advantages of premedication with sulphonamides are less marked. The complications of this treatment and means for their prevention have been discussed.

\section{Conclusions}

(1) High fever mechanically produced is the treatment of choice for resistant gonococcal urethritis.

(2) It is much more effective when combined with sulphonamide premedication.

(3) The duration of fever required varied with the individual case but sessions of six and eight hours produced a high proportion of successes.

(4) Cases in which hyperthermia was not followed by immediate cure frequently responded to measures which had previously failed.

(5) This treatment was less effective but still of value in the treatment of resistant cases of non-specific urethritis.

(6) The potential dangers of this treatment can be reduced to a minimum by careful and skilful technique.

Our thanks are due to Brig. T. E. Osmond, A.M.S., for constant encouragement and support and to Col. G. P. Kidd, M.C., A.M.S., for permission to publish these results. Acknowledgments are also due to Professor R. A. Peters and Dr. R. S. Thompson, for helpful advice and for making available supplies of cysteine ester.

\section{REFERENCES}

Batchelor, R. C. L., Thomson, G. M., and Huggan, J. L. (1942) Edinb. med. J., 49, 584.

Belt, E., and Folkenberg, A. W. (1940) Arch. phys. Ther., 21, 203.

Code, C. F. (1943) Personal communication.

Cullen, S. C., Weir, E. F., and Cook, Evelyn (1942) Anesthesiologv, 3, 123.

Ferguson, C., Buchholtz, M., Gersten, S., and Cutler, J. (1942) Vener. Dis. Inform., 23, 377.

Kendell, H. W. (1943) Personal communication.

Miller, L. L., and Whipple, G. H. (1940) Amer. J. med. Sci., 199, 204.

- - (1942) J. exp. Med., 76, 421.

- Ross, J. F., and Whipple, G. H. (1940) Amer. J. med. Sci., $200,739$.

Rose, D. L., Kendell, H. W., and Simpson, W.M. (1941) War Med., 1, 470.

Simpson, W. M., Rose, D. L., and Kendell, H.W . (1941) Brit. J. vener. Dis., 17, 185.

\section{Treatment of fusospirillary balanitis}

Local treatment with a preparation of stovarsol containing merfenil, 1 in 100,000 , is advocated for balanitis circinata by G. M. Thomson in cases where fusospirillary infection is found on bacteriological investigation. The use of this preparation, following local hygiene with saline, in thirty-eight cases gave'excellent results in all, healing having been attained in an average of 3.5 days.-British Medical Journal, 16th October, 1943.

\section{Incidence of syphilis among juvenile mental defectives}

The incidence of syphilis among juvenile mental defectives of low grade was investigated by $\mathrm{J}$. Lloyd in hospital inmates during the years 1938-42. In a total of 512 children whose average age was 5.5 years he found the blood Wassermann reaction to be positive in four cases only $(0.78$ per cent). He points out that among older mental defectives a positive blood Wassermann reaction is much commoner than in this group and infers that syphilis appears to be decreasing among parents of mental defectives, although a possible alternative explanation of the results is that an increasing proportion of mothers may have been receiving treatment.-British Medical Journal, 2nd October, 1943. 